\title{
PENGARUH KONSENTRASI DAN LAMA PERENDAMAN DALAM LARUTAN KAPUR SIRIH TERHADAP MUTU KERIPIK PISANG KEPOK (Musa paradisiaca formatypica)
}

\section{Afe Dwiani*, Suburi Rahman'}

${ }^{1}$ Program Studi Teknologi Hasi Pertanian, Fakultas Pertanian, Universitas Nahdlatul Wathan Mataram, Indonesia

*Co-author: dwiania@rocketmail.com

Article Information
History:
Received: $24-08-2021$
Accepted: $27-10-2021$

\section{Keywords:}

Calcium hydroxide

Chips

Plantain

Soaking time

\section{A. LATAR BELAKANG}

Produk hasil pertanian andalan kategori buahbuahan di Nusa Tenggara Barat (NTB) adalah buah pisang. Hal ini dibuktikan dengan meningkatnya hasil panen buah pisang dari tahun ke tahun yaitu 928.559 kuintal pada tahun 2018 dan 1.021.157 kuintal pada tahun 2019 (Badan Pusat Statistik, 2020).

Selain harganya yang terjangkau pisang juga dapat dikonsumsi dalam keadaan segar ataupun diolah terlebih dahulu (Imelda, Wulansari dan Sari, 2018). Produk komersil yang terbuat dari pisang adalah pure kaleng/beku, tepung, flakes, keripik, pisang kaleng dan selai (Oo dan Win, 2011).

\section{ABSTRACT}

Fis: Pisang merupakan hasil pertanian yang banyak dimanfaatkan terutama dalam pembuatan keripik. Keripik merupakan salah satu camilan yang memiliki karakteristik ertentu terutama teksturnya. Penelitian ini bertujuan mengetahui pengaruh konsentrasi paradisiaca formatypica). Metode yang digunakan adalah Rancangan Acak Lengkap (RAL) 20 dan 30 menit) sebagai berikut KP1 (1\%: 10 menit), KP2 (5\%: 10 menit), KP3 (10\%:10 menit), KP4 (1\%: 20 menit), KP5 (5\%: 20 menit), KP6 (10\%: 20 menit), KP7 (1\%: 30 menit), KP8 (5\%: 30 menit) dan KP9 (10\%: 30 menit). Data hasil pengamatan dianalisis dengan menggunakan analisa keragaman pada taraf nyata $5 \%$ dan apabila terdapat beda penelitian menunjukkan bahwa konsentrasi dan lama perendaman kapur sirih berpengaruh secara nyata terhadap mutu kimia (air, abu, lemak dan seng/Zn) dan organoleptik (rasa, warna, aroma dan tekstur)pada keripik pisang kepok. Untuk parameter kadar seng/Zn, seluruh perlakuan memenuhi standar keripik pisang (SNI No. 01-4315), sedangkan untuk kadar air, abu dan lemak belum semua perlakuan memenuhi syarat mutu SNI. Untuk parameter organoleptik rasa, warna dan aroma dihasilkan perlakuan yang disukai panelis adalah perlakuan KP1 ((konsentrasi kapur sirih 1\% dan lama perendaman 10 menit) sedangkan untuk tekstur adalah perlakuan KP9 (konsentrasi kapur sirih 10\% dan lama

Abstract: This research aimed to determine the effect of concentration and soaking time in calcium hydroxide $(\mathrm{Ca}(\mathrm{OH}) 2)$ on the quality of plantain chips (Musa paradisiaca formatypica). The method that used in this study was complete randomized design (CRD) with a double factors that was concentration of calcium hydroxide (1\%,5\% and $10 \%)$ and soaking time (10, 20 and 30 minutes), with treatment are KP1 (1\%: 10 minutes), KP2 (5\%: 10 minutes), KP3 (10\% : 10 minutes), KP4 (1\%: 20 minutes), KP5 (5\% : 20 minutes), KP6 (10\%: 20 minutes), KP7 (1\%: 30 minutes), KP8 (5\%:30 minutes) and KP9 (10\%: 30 minutes). The data of the research were analyzed using Analysis of Variance at level $5 \%$ and tested continued using the test of Least Significant Different (LSD) at the same level if there was a real difference. The results showed that the concentration and soaking time in calcium hydroxide had a real effect on chemical qualities (water, ash, fat, and zinc/Zn) and organoleptic (taste, color, aroma, and texture) of plantain chips. In zinc content for all moisture, ash, and fat content, not all treatments are suitable with the standard. In organoleptic parameters for taste, color, and aroma, panelists preferred treatment of KP1 (concentration of calcium hydroxide $1 \%$ and soaking time of 10 minutes) for best result, while for texture the treatment of KP9 (concentration of calcium hydroxide 10\% and soaking time 30 minutes) produces the best quality based from panelist choice.
Keripik pisang adalah salah satu pengolahan pisang dengan cara digoreng menggunakan banyak minyak. Umumnya keripik ini dibuat menggunakan pisang setengah matang yang diiris tipis dan digoreng menggunakan minyak sawit ataupun minyak kelapa (Aida et al., 2016). Penggorengan adalah salah satu jenis pengolahan dengan cara mengurangi kadar air dari bahan pangan menggunakan media minyak/lemak. Pengurangan air bertujuan untuk meningkatkan daya simpan bahan pangan (Yulhaidir, Rasyid dan Jumawan, 2021). Kualitas utama yang harus dimiliki produk keripik pisang adalah tekstur/kerenyahan. MenurutStandar Nasional Indonesia (SNI) bahwa salah 
satu syarat mutu keripik pisang adalah tekstur yang renyah (Badan Standarisasi Nasional, 1996).

Salah satu bahan yang dapat meningkatkan tekstur keripik yaitu kalsium hidroksida $\left(\mathrm{Ca}(\mathrm{OH})_{2}\right)$. Kalsium berperan untuk meningkatkan kekerasan pada dinding sel, menghambat lunaknya jaringan juga menurunkan aktifitas enzim pektinase yang bertanggung jawab terhadap degradasi pada dinding sel (Vicente et al., 2009). Kalsium juga berfungsi untuk membuat buah menjadi kaku agar kualitasnya lebih baik (Lurie, 2009).

Beberapa penelitian keripik buah menggunakan kalsium hidroksida $\left(\mathrm{Ca}(\mathrm{OH})_{2}\right)$ sebagai bahan yang meningkatkan tekstur keripik seperti keripik talas sutra (perlakuan terbaik adalahpenambahan larutan kapur sebesar $15 \%$ dan perendaman 15 menit) (Chairuni et al., 2020); keripik kentang (perlakuan terbaik adalah perendaman $1 \%$ selama 30 menit) (Mandei dan Nuryadi, 2017); keripik papaya (perlakuan terbaik padakonsentrasi $0,15 \%$ dan waktu rendam 15 menit) (Yunus, Syam dan Jamaluddin, 2017), keripik nanas (perlakuan terbaik dihasilkan larutan kapur sirih sejumlah $3 \%$ dan waktu rendam 3 jam) (Rusly, 2018)dan keripik biji durian (perlakuan terbaik pada lama perendaman 4 jam dan konsentrasi kapur sirih 0,5\%) (Siregar, Setyohadi dan Nurminah, 2015).

Saat ini penelitian tentang keripik pisang yang diberi perlakuan perendaman kapur sirih sangat sedikit dilakukan. Oleh karena itu dilakukan penelitian dengan judul pengaruh konsentrasi dan lama perendaman kapur sirih terhadap kandungan mutu keripik pisang.

\section{B. METODE PENELITIAN}

\section{Bahan dan Alat}

Adapun bahan-bahan yang digunakan dalam penelitian ini adalah pisang kepok berumur 80 hari (setengah matang), air, kapur sirih, minyak goreng, garam, gula, aquades dan pelarut lemak (heksan). Peralatan yang digunakan adalah kompor gas, wajan, pisau, talenan, baskom plastik, baskom stainless steel, glassware, pipet volum, timbangan kasar, timbangan analitik, botol timbang, oven, desikator, cawan abu, tanur, labu soxhlet, kertas label, kertas saring dan spektrofotometer serapan atom (AAS).

\section{Pembuatan Keripik Pisang}

Pisang disortasi, dikupas dan dicuci, kemudian diiris dengan menggunakan alat slicer manual. Setelah itu irisan pisang direndam dalam larutan kapur sirih (sesuai perlakuan). Irisan pisang kemudian ditiriskan dan digoreng hingga garing pada suhu $130^{\circ} \mathrm{C}$. Keripik pisang yang telah matang kemudian di tiriskan dan dikemas untuk dianalisa lebih lanjut.

\section{Uji Kimia dan Organoleptik}

Analisa yang digunakan dalam penelitian ini adalah kadar air, kadar abu dan kadar lemak (AOAC, 1995), serta Zn (seng) dengan Alat AAS/Automic
Absorbtion Spectrophotometer Flamedan uji Organoleptik (warna, aroma, tekstur dan rasa) (Krissetiana, 2015).

\section{Analisis Statistik}

Penelitian ini dirancang menggunakan Rancangan Acak Lengkap (RAL) dengan 2 faktor yaitu penambahan kapur sirih (1,5 dan $10 \%)$ dan waktu rendam (10, 20 dan 30 menit) menghasilkan kombinasi sebanyak 9 perlakuan dan 2 ulangan sehingga didapat 18 unit percobaan.Data hasil pengamatan dianalisis menggunakan ANOVA (Analysis of Variance) dengan Microsoft Excel dan Program Co-STAT. Apabila hasil analisis memberikan pengaruh yang berbeda nyata (signifikan), maka akan dilakukan uji lanjut dengan uji BNT (Beda Nyata Terkecil) dengan taraf 5\%. Rancangan penelitian dapat dilihat pada Tabel 1.

Tabel 1 . Rancangan Penelitian

\begin{tabular}{ccc}
\hline Perlakuan & $\begin{array}{c}\text { Konsentrasi } \\
\text { Kapur sirih (\%) }\end{array}$ & $\begin{array}{c}\text { Lama } \\
\text { Perendaman } \\
\text { (menit) }\end{array}$ \\
\hline KP1 & 1 & 10 \\
KP2 & 5 & 10 \\
KP3 & 10 & 10 \\
KP4 & 1 & 20 \\
KP5 & 5 & 20 \\
KP6 & 10 & 20 \\
KP7 & 1 & 30 \\
KP8 & 5 & 30 \\
KP9 & 10 & 30 \\
\hline
\end{tabular}

\section{HASIL DAN PEMBAHASAN}

\section{Hasil Analisa Ragam Parameter Kimia dan Organoleptik}

Berikut ini merupakan hasil analisa ragam parameter kimia dan organoleptik keripik pisang kepok dengan perlakuan konsentrasi dan lama perendaman larutan kapur sirih yang dapat dilihat pada Tabel 2.

Tabel 2.

Hasil Analisa Ragam Parameter Mutu Kimia dan Organoleptik Keripik Pisang Kepok

\begin{tabular}{lc}
\hline \multicolumn{1}{c}{ Parameter } & Hasil \\
\hline Kimia: & \\
Kadar air (\%) & $\mathrm{S}$ \\
Kadar abu (\%) & $\mathrm{S}$ \\
Kadar lemak (\%) & $\mathrm{S}$ \\
Kadar Zn (mg/100 g) & $\mathrm{S}$ \\
Organoleptik: & \\
Warna & $\mathrm{S}$ \\
Aroma & $\mathrm{S}$ \\
Tekstur & $\mathrm{S}$ \\
Rasa & $\mathrm{S}$ \\
\hline
\end{tabular}

Keterangan : $\mathrm{S}=$ Signifikan (berbeda nyata); NS = Non Signifikan (tidak berbeda nyata)

Berdasarkan Tabel 2 dapat dilihat bahwa konsentrasi dan lama perendaman dalam larutan kapur sirih memberikan pengaruh nyata terhadap parameter kimia yaitu kadar air, abu, lemak dan zn serta 
organoleptik yaitu warna, aroma, tekstur dan rasa (hedonik). Purata dan uji lanjut BNT 5\% perlakuan konsentrasi dan lama perendaman larutan kapur sirih terhadap parameter kimia keripik pisang.

Purata hasil pengamatan dan uji lanjut BNT 5\% terhadap kadar air, kadar abu lemak dan zn dapat dilihat pada Tabel 3, sedangkan purata hasil pengamatan dan uji lanjut BNT 5\% terhadap organoleptik warna, aroma, tekstur dan rasa (hedonik) dapat dilihat pada Tabel 4 .

Tabel 3.

Purata dan Uji Lanjut BNT 5\% Perlakuan

Konsentrasi dan Lama Perendaman Larutan Kapur Sirih Terhadap Parameter Kimia Keripik Pisang

\begin{tabular}{|c|c|c|c|c|}
\hline \multirow[b]{2}{*}{ Perlakuan*) } & \multicolumn{4}{|c|}{ Purata } \\
\hline & $\begin{array}{c}\text { Kadar } \\
\text { Air } \\
\text { (\%) }\end{array}$ & $\begin{array}{c}\text { Kadar } \\
\text { Abu } \\
\text { (\%) }\end{array}$ & $\begin{array}{c}\text { Kadar } \\
\text { Lemak } \\
(\%)\end{array}$ & $\begin{array}{c}\mathrm{Zn} \\
(\mathrm{mg} / \mathrm{kg})\end{array}$ \\
\hline KP1 & $7,19^{a}$ & $1,73^{\mathrm{i}}$ & $33,45^{\mathrm{a}}$ & $0,78^{\mathrm{i}}$ \\
\hline KP2 & $6,89^{b}$ & $2,07^{\mathrm{f}}$ & $32,28^{b}$ & $0,83^{f}$ \\
\hline $\mathrm{KP}_{3}$ & $6,76^{\mathrm{bc}}$ & $2,28^{\mathrm{e}}$ & $31,53^{b c}$ & $0,87^{\mathrm{a}}$ \\
\hline $\mathrm{KP}_{4}$ & $6,47^{\mathrm{d}}$ & $1,87^{\mathrm{h}}$ & $30,82^{c}$ & $0,79^{\mathrm{h}}$ \\
\hline $\mathrm{KP}_{5}$ & $6,5^{2^{\mathrm{cd}}}$ & $2,39^{\mathrm{d}}$ & $29,52^{\mathrm{d}}$ & $0,84^{\mathrm{e}}$ \\
\hline KP6 & $5,88^{\mathrm{e}}$ & $2,47^{\mathrm{c}}$ & $28,54^{\mathrm{e}}$ & $0,86^{\mathrm{c}}$ \\
\hline KP7 & $5,50^{f}$ & $1,93^{\mathrm{g}}$ & $28,40^{\mathrm{e}}$ & $0,80^{g}$ \\
\hline KP8 & $4,55^{\mathrm{g}}$ & $2,5^{2^{b}}$ & $27,21^{f}$ & $0,85^{\mathrm{d}}$ \\
\hline KP9 & $4,22^{\mathrm{h}}$ & $2,61^{\mathrm{a}}$ & $26,29^{f}$ & $0,87^{\mathrm{b}}$ \\
\hline
\end{tabular}

Keterangan: huruf yang sama pada kolom yang sama menunjukkan tidak ada perbedaan nyata pada taraf nyata $5 \%$. *)Perlakuan :

$\mathrm{KP} 1=$ Kapur sirih $1 \%:$ perendaman 10 menit $\mathrm{KP} 2=$ Kapur sirih 5\% : perendaman 10 menit $\mathrm{KP} 3=$ Kapur sirih 10\% : perendaman 10 menit $\mathrm{KP} 4=$ Kapur sirih 1\% : perendaman 20 menit $\mathrm{KP}_{5}=$ Kapur sirih $5 \%:$ perendaman 20 menit KP6 = Kapur sirih 10\% : perendaman 20 menit $\mathrm{KP} 7=$ Kapur sirih $1 \%$ : perendaman 30 menit KP8 $=$ Kapur sirih $5 \%:$ perendaman 30 menit KP9 = Kapur sirih 10\% : perendaman 30 menit

Tabel 4.

Purata dan Uji Lanjut BNT 5\% Perlakuan Konsentrasi dan Lama Perendaman Larutan Kapur Sirih Terhadap Parameter Organoleptik Hedonik Keripik Pisang

\begin{tabular}{ccccc}
\hline \multirow{2}{*}{ Perlakuan*) $^{*}$} & \multicolumn{4}{c}{ Purata } \\
\cline { 2 - 5 } & $\begin{array}{c}\text { Rasa } \\
\text { (skor) }\end{array}$ & $\begin{array}{c}\text { Warna } \\
\text { (skor) }\end{array}$ & $\begin{array}{c}\text { Aroma } \\
\text { (skor) }\end{array}$ & $\begin{array}{c}\text { Tekstur } \\
\text { (skor) }\end{array}$ \\
\hline $\mathrm{KP1}$ & $4,20^{\mathrm{a}}$ & $4,30^{\mathrm{a}}$ & $4,70^{\mathrm{a}}$ & $3,05^{\mathrm{a}}$ \\
$\mathrm{KP2}$ & $4,00^{\mathrm{b}}$ & $4,00^{\mathrm{abc}}$ & $4,35^{\mathrm{ab}}$ & $3,90^{\mathrm{ab}}$ \\
$\mathrm{KP} 3$ & $3,95^{\mathrm{ab}}$ & $3,95^{\mathrm{abc}}$ & $4,00^{\mathrm{bc}}$ & $4,15^{\mathrm{bc}}$ \\
$\mathrm{KP} 4$ & $3,65^{\mathrm{bc}}$ & $4,10^{\mathrm{ab}}$ & $4,35^{\mathrm{ab}}$ & $4,35^{\mathrm{ab}}$ \\
$\mathrm{KP} 5$ & $3,65^{\mathrm{bc}}$ & $3,70^{\mathrm{bcd}}$ & $3,60^{\mathrm{cd}}$ & $4,40^{\mathrm{cd}}$ \\
$\mathrm{KP6}$ & $3,40^{\mathrm{cd}}$ & $3,55^{\mathrm{cd}}$ & $3,30^{\mathrm{e}}$ & $4,50^{\mathrm{e}}$ \\
$\mathrm{KP} 7$ & $3,35^{\mathrm{cd}}$ & $3,95^{\mathrm{abc}}$ & $3,65^{\mathrm{cd}}$ & $4,65^{\mathrm{cd}}$ \\
$\mathrm{KP} 8$ & $3,30^{\mathrm{cd}}$ & $3,60^{\mathrm{bcd}}$ & $3,40^{\mathrm{e}}$ & $4,64^{\mathrm{e}}$ \\
$\mathrm{KP} 9$ & $3,00^{\mathrm{d}}$ & $3,40^{\mathrm{d}}$ & $3,05^{\mathrm{e}}$ & $4,80^{\mathrm{e}}$ \\
\hline
\end{tabular}

Keterangan:

$\mathrm{KP} 1=$ Kapur sirih 1\% : perendaman 10 menit $\mathrm{KP} 2=$ Kapur sirih 5\% : perendaman 10 menit $\mathrm{KP} 3$ = Kapur sirih 10\%: perendaman 10 menit $\mathrm{KP} 4=$ Kapur sirih 1\% : perendaman 20 menit $\mathrm{KP}_{5}=$ Kapur sirih $5 \%$ : perendaman 20 menit KP6 = Kapur sirih 10\% : perendaman 20 menit $\mathrm{KP} 7=$ Kapur sirih 1\%: perendaman 30 menit KP8 $=$ Kapur sirih 5\% : perendaman 30 menit $\mathrm{KP} 9=$ Kapur sirih 10\% : perendaman 30 menit

\section{Parameter Kimia}

\section{a. Kadar Air}

Kadar air keripik pisang dengan konsentrasi dan lama perendaman larutan kapur sirih memiliki perbedaan yang nyata (Tabel 2). Kadar air keripik pisang berkisar antara 4,22\%-7,19\%. Kadar air terendah terdapat pada perlakuan KP9 (kapur sirih 10\% : perendaman 30 menit), sementara kadar air tertinggi dihasilkan perlakuan KP1 (kapur sirih 1\%: perendaman 10 menit). Kadar air keripik pisang kepok pengaruh perlakuan dapat dilihat di Tabel 3.

Dari Tabel tersebut dapat dilihat bahwa semakin tinggi konsentrasi kapur sirih dan semakin lama waktu perendamannya maka dihasilkan keripik pisang kepok yang kadar airnya semakin rendah. Hal ini sama dengan hasil penelitian pada keripik biji durian (Siregar, Setyohadi dan Nurminah, 2015) dan pada tepung biji durian (Simanjuntak, 2017). Selain itu penelitian pada keripik papaya dengan perlakuan konsentrasi dan lama perendaman kapur sirih juga diperoleh hasil yang sama (Yunus, Syam dan Jamaluddin, 2017).

Hal ini disebabkan oleh waktu rendam yanglama dan kalsium masuk ke dalam jaringan buah, berikatan dengan gugus karboksil pada pektin, sehingga perendaman menghasilkan produk dengan kadar air rendah(Astuti, Yuliani dan Rahmadi, 2019). Kadar air maksimal yang ditetapkan dalam SNI untuk produk keripik pisang yaitu maksimal 6\%. Kadar air yang memenuhi SNI terdapat pada perlakuan KP6 sampai KP9. Dengan kadar air yang rendah maka diharapkan produk dapat awet, di samping itu juga produk memiliki sifat kerenyahan yang baik.

\section{b. Kadar abu}

Kadar abu keripik pisang dengan konsentrasi dan lama perendaman larutan kapur sirih memiliki perbedaan yang nyata (Tabel 2).Kadar abu keripik pisang berkisar antara1,73\%-2,61\%. Perlakuan KP6 (kapur sirih 10\% : perendaman 20 menit) menghasilkan kadar abu paling tinggi sedangkan perlakuan KP1 (kapur sirih 1\% : perendaman 10 menit) menghasilkan kadar abu terendah. Kadar abu keripik pisang kepok pengaruh perlakuan dapat dilihat pada Tabel 3 .

Dari Tabel di atas dapat dilihat bahwa semakin tinggi konsentrasi kapur sirih dan semakin lama waktu perendamannya maka dihasilkan keripik pisang kepok yang kadar abunya yang semakin tinggi. Hal ini disebabkan oleh bertambahnya mineral dalam pisang saat perendaman dalam larutan kapur sirih menyebabkan peningkatan mineral dalam keripik dan memberikan hasil kadar abu yang tinggi. Semakin tinggi konsentrasi dan waktu perendaman dalam kapur sirih, maka dihasilkan keripik biji durian dengan kadar abu yang tinggi 
(Siregar, Setyohadi dan Nurminah, 2015). Perlakuan perendaman dalam kapur sirih akan menyebabkan mineral tertinggal sehingga akan meningkatkan kadar abu bahan(Suprapto, 2004).

Kadar abu keripik pisang sebagian besar berada di atas kadar abu maksimal yang ditetapkan dalam SNI untuk produk keripik pisang (maks. 2\%). Kadar abu yang memenuhi standar dihasilkan perlakuan KP1(kapur sirih $1 \%$ : perendaman 10 menit) hingga $\mathrm{KP}_{4}$ (kapur sirih $1 \%$ : perendaman 20 menit) dan $\mathrm{KP}_{7}$ (kapur sirih $1 \%$ : perendaman 30 menit) sedangkan perlakuan lainnya melebihi batas maksimal yang ditetapkan SNI.

a. Kadar Lemak

Kadar lemak pada keripik pisang dengan konsentrasi dan lama perendaman larutan kapur sirih memiliki perbedaan yang nyata (Tabel 2). Kadar lemak keripik pisang berkisar antara 26,29\%-33,45\%. Kadar lemak tertinggi dihasilkan perlakuan KP1 (kapur sirih 1\% : perendaman 10 menit) dan untuk kadar lemak terendah dihasilkan perlakuan KP9 (kapur sirih 10\% : perendaman 30 menit). Kadar lemak keripik pisang kepok pengaruh perlakuan dapat dilihat pada Tabel 3 .

Dari Tabel tersebut dapat dilihat bahwa semakin tinggi konsentrasi dan waktu perendaman kapur sirih maka dihasilkan kadar lemak yang semakin rendah. Hal ini karena kapur sirih akan meningkatkan hidrolisis lemak. Suasana basa akan meningkatkan proses hidrolisis lemak dan membuat kadar lemak menjadi rendah.

Proses hidrolisis lemak merupakan tanda-tanda kerusakan pada lemak. Proses ini semakin cepat jika terdapat basa, asam maupun enzim. Kalsium hidroksida $\left(\mathrm{Ca}(\mathrm{OH})_{2}\right)$ adalahjenis basa dengan kekuatan sedang yang dapat mempengaruhi reaksi hidrolisis(Winarno, 2008).Pada keripik biji durian dihasilkan kadar lemak yang rendah dengan semakin banyaknya kapur sirih yang ditambahkan (Siregar, Setyohadi dan Nurminah, 2015), begitu pula yang dihasilkan pada penelitian tepung biji durian (Simanjuntak, 2017).

Kadar lemak sebagian perlakuan masih berada dalam standar kadar lemak maksimal yang ditetapkan dalam SNI untuk produk keripik pisang, yaitu maksimal 30\%. Kadar lemak yang memenuhi standar adalah pada perlakuan $\mathrm{KP}_{5}$ hingga KP9.

b. Kadar seng (Zn)

Kadar seng (Zn) keripik pisang dengan konsentrasi dan lama perendaman kapur sirih memiliki perbedaan yang nyata (Tabel 2). Kadar Zn keripik pisang berkisar antara $0,78 \mathrm{mg} / \mathrm{kg}-0,87$ $\mathrm{mg} / \mathrm{kg}$. Kadar $\mathrm{Zn}$ terendah dihasilkan pada perlakuan KP1 (kapur sirih 1\% : perendaman 10 menit) sedangkan kadar seng tertinggi dihasilkan pada perlakuan $\mathrm{KP}_{3}$ (kapur sirih 10\% : perendaman
10 menit). Kadar Zn keripik pisang kepok pengaruh perlakuan dapat dilihat pada Tabel 3 .

Dari Tabel tersebut dapat dilihat bahwa semakin tinggi konsentrasi dan waktu perendaman kapur sirih maka kadar Zn akan semakin tinggi. Kadar Zn semua perlakuan masih berada dalam standar kadar Zn maksimal yang ditetapkan dalam SNI untuk produk keripik pisang, yaitu maksimal $40 \mathrm{mg} / \mathrm{kg}$. Pada produk keripik dinyatakan bahwa $\mathrm{Zn}$ merupakan cemaran dari unsur logam, yang dapat membahayakan kesehatan apabila melebihi ambang batas yang ditetapkan (Badan Standarisasi Nasional, 1996). Hasil penelitian ini menunjukkan bahwa keripik pisang masih aman dari cemaran logam $\mathrm{Zn}$ sehingga aman untuk dikonsumsi. Selain itu kandungan mineral $\mathrm{Zn}$ pada pisang sangat rendah.

\section{Parameter Organoleptik}

\section{a. Rasa}

Skor rasa yang dihasilkan keripik pisang dengan perlakuan konsentrasi dan lama perendaman kapur sirih berkisar antara 3 (agak suka) - 4,2 (suka). Skor rasa terendah dihasilkan perlakuan KP9 (kapur sirih 10\% : perendaman 30 menit) dengan nilai 3 (agak suka) sedangkan skor tertinggi dihasilkan perlakuan KP1 (kapur sirih 1\% : perendaman 10 menit) dengan nilai 4,2 (suka). Rasa keripik pisang kepok pengaruh perlakuan dilihat pada Tabel 4.

Dari Tabel tersebut dapat dilihat bahwa konsentrasi kapur sirih dan perendaman menghasilkan pengaruh yang berbeda nyata $(\alpha=0,05)$ terhadap nilai organoleptik rasa. Semakin tinggi konsentrasi dan waktu perendaman maka nilai organoleptik rasa pada keripik pisang semakin menurun. Rasa keripik akan semakin menurun dengan semakin meningkatnya konsentrasi dan lama perendaman kapur sirih. Kapur sirih dapat mempengaruhi rasa asli dari produk tersebut. Proses perendaman dengan waktu yang lama juga dapat membuat kapur sirih terserap lebih banyak ke dalam bahan sehingga mempengaruhi penilaian panelis (Siregar, Setyohadi dan Nurminah, 2015).

\section{b. Warna}

Skor warna yang dihasilkan keripik pisang dengan perlakuan konsentrasi dan lama perendaman kapur sirih berkisar antara 3,40 (agak suka) - 4,30 (suka). Skor rasa terendah dihasilkan perlakuan KP9 (kapur sirih 10\% : perendaman 30 menit) dengan nilai 3,4 (agak suka) sedangkan skor tertinggi dihasilkan perlakuan KP1 (kapur sirih 1\% : perendaman 10 menit) dengan nilai 4,3 (suka). Warna keripik pisang kepok pengaruh perlakuan dapat dilihat pada Tabel 4 .

Dari Tabel tersebut dapat dilihat bahwa konsentrasi kapur sirih dan perendaman 
menghasilkan pengaruh yang berbeda nyata $(\alpha=0,05)$ terhadap nilai organoleptik warna. Semakin tinggi kapur sirih dan waktu perendamannya maka nilai organoleptik warna keripik pisang yang dihasilkan akan semakin menurun. Hal ini karena kapur sirih menyebabkan warna keripik yang dihasilkan menjadi kuning kecoklatan dan coklat kehitaman.

Kapur sirih akan mempengaruhi kerusakan pada pigmen bahan yang membuat warna bahan menjadi berubah. Hal ini karena selama proses pengolahan, pigmen akan dipengaruhi oleh bahan kimia, fisik dan mekanik(Winarno, 2008). Warna keripik durian akan semakin menurun dengan semakin meningkatnya konsentrasi dan lama perendaman kapur sirih (Siregar, Setyohadi dan Nurminah, 2015).

\section{c. Aroma}

Skor aroma yang dihasilkan keripik pisang dengan perlakuan konsentrasi dan lama perendaman kapur sirih berkisar antara 3,05 (agak suka) - 4,7 (suka). Skor rasa terendah dihasilkan perlakuan KP9 (kapur sirih 10\% : perendaman 30 menit) dengan nilai 3,05 (agak suka) sedangkan skor tertinggi dihasilkan perlakuan KP1 (kapur sirih 1\% : perendaman 10 menit) dengan nilai 4,7 (suka). Aroma keripik pisang kepok pengaruh perlakuan dapat dilihat pada Tabel 4.

Dari Tabel tersebut dilihat bahwa konsentrasi kapur sirih dan perendamanmenghasilkan pengaruh yang berbeda nyata $(\alpha=0,05)$ terhadap nilai organoleptik aroma. Semakin tinggi kapur sirih dan waktu perendamannya maka nilai organoleptik aroma keripik pisang yang dihasilkan akan semakin menurun atau kurang disukai panelis. Penyebabnya adalah waktu perendaman yang lama mengakibatkan banyak kalsium yang tertinggal pada bahan sehingga aroma kapur sirih masih tercium. Kalsium juga dapat meninggalkan rasa pahit pada buah. Oleh karena itu panelis lebih memilih perlakuan dengan konsentrasi dan lama perendaman minimal (Saftner et al., 2003).

\section{d. Tekstur}

Skor tekstur yang dihasilkan keripik pisang dengan perlakuan konsentrasi dan lama perendaman kapur sirih berkisar antara 3,05 (agak suka) $-4,8$ (suka). Skor tekstur terendah dihasilkan perlakuan KP1 (kapur sirih 1\% : perendaman 10 menit) dengan nilai 3,05 (agak suka) sedangkan skor tertinggi dihasilkan perlakuan KP9 (kapur sirih 10\% : perendaman 30 menit) dengan nilai 4,80 (suka). Tekstur keripik pisang kepok pengaruh perlakuan dapat dilihat pada Tabel 4 .

Dari Tabel tersebut dapat dilihat bahwa konsentrasi kapur sirih menghasilkan pengaruh yang berbeda nyata $(\alpha=0,05)$ terhadap nilai organoleptik tekstur. Semakin tinggi penggunaan kapur sirih dan waktu perendamannya maka nilai organoleptik tesktur keripik pisang akan semakin tinggi atau semakin disukai panelis. Hal ini karena masuknya kapur dalam bahan dan mengikat air sehingga air akan berkurang dan merubah tekstur menjadi renyah. Pada buah, pektin akan mengikat kapur sirih sehingga tekstur buah berubah menjadi keras (Yunus, Syam dan Jamaluddin, 2017).

Ini juga terjadi pada produk keripik kentang dimana perendaman menggunakan larutan kapur akan membentuk ikatan kalsium dan pektin dan tekstur berubah menjadi keras (Mandei dan Nuryadi, 2017). Hal ini sesuai dengan penelitian pada produk keripik papaya(Yunus, Syam dan Jamaluddin, 2017), pada produk keripik talas sutra (Chairuni et al., 2020) dan pada produk keripik durian(Siregar, Setyohadi dan Nurminah, 2015). Produk yang memiliki keriteria renyah dan sesuai dengan syarat mutu produk pisang adalah pada perlakuan KP2 hingga KP9 yang sesuai standar.

\section{SIMPULAN DAN SARAN}

Dari hasil analisa serta uraian di atas dapat ditarik kesimpulan sebagai berikut: perlakuan konsentrasi dan perendaman kapur sirih menghasilkan pengaruh yang berbeda nyata terhadap mutu kimia (kadar air, abu, lemak dan seng/Zn) dan organoleptik (rasa, warna, aroma dan tekstur) pada keripik pisang kepok. Berdasarkan SNI keripik pisang (No. 01-4315-1996) diketahui bahwa untuk kadar seng ( $\mathrm{Zn}$ ) pada semua perlakuan memenuhi syarat mutu SNI, namun untuk kadar air, abu dan lemak belum semua perlakuan memenuhi syarat mutu SNI. Untuk mutu organoleptik keripik pisang diketahui bahwa untuk parameter rasa, warna dan aroma perlakuan KP1 (kapur sirih 1\% : lama perendaman 10 menit) merupakan perlakuan terbaik sedangkan untuk parameter tekstur, perlakuan KP9 (kapur sirih 10\% : lama perendaman 30 menit) menghasilkan mutu terbaik yang disukai panelis.

\section{DAFTAR RUJUKAN}

Aida, S. A. et al. (2016) "A study on reducing fat content of fried banana chips using a sweet pretreatment technique," International Food Research Journal, 23(1), hal. 68-71.

\section{AOAC (1995) No Title. Washington: AOAC, I W.Gmc.}

Astuti, T. W., Yuliani dan Rahmadi, A. (2019) "Studi perendaman kulit buah naga super merah (Hylocereus costaricensis) dalam larutan bahan pengeras pada pengolahan manisan kering," Journal of Tropical AgriFood, 1(1), hal. 19-28. doi: 10.35941/jtaf.1.1.2019.2415.19-28.

Badan Pusat Statistik (2020) Provinsi Nusa Tenggara Barat Dalam Angka 2020. Diedit oleh BPS Provinsi Nusa Tenggara Barat. BPS Provinsi Nusa Tenggara Barat.

Badan Standarisasi Nasional (1996) Standar Nasional Indonesia Keripik Pisang. Diedit oleh Badan Standarisasi Nasional. Badan Standarisasi Nasional. 
Chairuni, A. R. et al. (2020) "Pengaruh konsentrasi larutan kapur sirih $\mathrm{Ca}(\mathrm{OH}) 2$ dan lama perendaman terhadap mutu keripik talas sutera (Colocasia esculenta L)," Jurnal Biology Education, 8(2), hal. 82-91.

Imelda, M., Wulansari, A. dan Sari, L. (2018) "PERBANYAKAN <em $>$ IN VITRO $</$ em $>$ PISANG KEPOK var. UNTI SAYANG TAHAN PENYAKIT DARAH MELALUI PROLIFERASI TUNAS," Jurnal Bioteknologi \& Biosains Indonesia (JBBI), 5(1), hal. 36. doi: 10.29122/jbbi.v5i1.2626.

Krissetiana, H. (2015) Uji organoleptik bahan pangan. Yogyakarta: Citra Aditya Bakti.

Lurie, S. (2009) Stress physiology and latent damage. Second. Diedit oleh W. J. Florkowski et al. USA: Elsevier Inc.

Mandei, J. H. dan Nuryadi, A. M. (2017) "Pengaruh cara perendaman dan jenis kentang terhadap mutu keripik kentang," Jurnal Penelitian Teknologi Industri, 9(2), hal. 123-136. doi: 10.33749/jpti.v9i2.3516.

Oo, K. S. dan Win, Y. Y. (2011) "Study on the Preparation of Banana Chips and Banana Powder," Universities Research Journal, 4(3), hal. 415-429.

Rusly, T. A. (2018) Pengaruh lama perendaman kapur sirih dan suhu penggorengan terhadap karakteristik keripik nanas menggunakan mesin vacuum fryer. UNIVERSITAS PASUNDAN.

Saftner, R. A. et al. (2003) "Sanitary dips with calcium propionate, calcium chloride, or a calcium amino acid chelate maintain quality and shelf stability of fresh-cut honeydew chunks," Postharvest Biology and Technology, 29(3), hal. 257-269. doi: 10.1016/So9255214(03)00041-3.

Simanjuntak, F. K. (2017) Pengaruh formulasi tepung komposit terhadap mutu muffin. UNIVERSITAS SUMATERA UTARA.

Siregar, N. E., Setyohadi dan Nurminah, M. (2015) "Pengaruh konsentrasi kapur sirih (kalsium hidroksida) dan lama perendaman terhadap mutu keripik biji durian (Effect of The Lime Concentration and Soaking Time on the Quality of Durian Stone Chips ),” 3(2), hal. 193-197.

Suprapto (2004) "Pengaruh lama blanching terhadap kualitas stik ubi jalar (Ipoema batatas L) dari tiga varietas," in D, P. et al. (ed.). Bogor: Puslitbang Peternakan.

Vicente, A. R. et al. (2009) Nutritional quality of fruits and vegetables. Second. Diedit oleh W. J. Florkowski et al. USA: Elsevier Inc.

Winarno, F. G. (2008) Kimia Pangan. Jakarta: PT Gramedia Pustaka Utama.

Yulhaidir, Rasyid, K. H. dan Jumawan, F. (2021) "Usaha jamur tiram di Desa Betao Kabupaten Sidrap,” Jurnal Pendidikan dan Pengabdian Masyarakat, 4(1), hal 104-108.

Yunus, R., Syam, H. dan Jamaluddin (2017) "Pengaruh persentase dan lama perendaman dalam larutan kapur sirih $\mathrm{Ca}(\mathrm{OH}) 2$ Terhadap kualitas keripik pepaya (Carica papaya L.) dengan vacuum frying," Jurnal Pendidikan Teknologi Pertanian, 3, hal. 221-233. doi: 10.26858/jptp.v3io.5721. 